\title{
Magdalena Owczarczuk
}

Uniwersytet w Białymstoku

e-mail: m.owczarczuk@uwb.edu.pl

\section{KULTUROWE PRZEJAWY NIESPÓJNOŚCI SYSTEMÓW INSTYTUCJONALNYCH KRAJÓW EUROPY ŚRODKOWEJ I WSCHODNIEJ}

\section{CULTURAL SYMPTOMS OF INCONSISTENCIES IN THE INSTITUTIONAL SYSTEMS OF CENTRAL AND EASTERN EUROPEAN COUNTRIES}

DOI: $10.15611 /$ pn.2017.493.04

JEL Classification: E02, P20, P37, Z13

Streszczenie: W artykule podjęto problem niespójności systemów instytucjonalnych postkomunistycznych krajów Europy Środkowej i Wschodniej (EŚiW) należących obecnie do Unii Europejskiej. Zakłada się, że istotnym elementem sprawności instytucji jest nie tylko ich jakość, ale również wewnętrzna spójność rozumiana jako dopasowanie formalnych elementów układu instytucjonalnego do ukształtowanych kulturowo instytucji nieformalnych. Wśród wielu aspektów niespójności instytucjonalnej te o podłożu i charakterze kulturowym jawią się jako niezwykle istotne. Niesprawne instytucje w krajach postkomunistycznych umożliwiają społeczeństwu utrwalanie postaw związanych z łamaniem podstawowych zasad funkcjonowania gospodarki rynkowej czy demokratyzacji życia społecznego. W związku z tym w artykule dokonano porównania krajów EŚiW pod kątem wybranych przejawów niespójności systemów instytucjonalnych, mających swe podłoże w kulturowo zakorzenionych postawach i wartościach społeczeństw tych państw. Tym samym - pośrednio - autorka wskazuje na istotną rolę instytucji nieformalnych w tworzeniu spójnych systemów instytucjonalnych gospodarek krajów EŚiW.

Słowa kluczowe: instytucje nieformalne, transformacja, kraje postkomunistyczne, korupcja, zaufanie.

Summary: The article addresses the problem of inconsistencies in the institutional systems of post-communist countries of Central and Eastern Europe (CEE) currently belonging to the European Union. It is assumed that an important element of institutional efficiency is not only their quality but also internal coherence, understood as matching the formal elements of the institutional system to culturally-shaped informal institutions. Among many aspects of institutional inconsistency, those of cultural origin and character appear to be extremely important. Inefficient institutions in post-communist countries enable the society to strengthen the attitudes of breaking the basic principles of functioning of a market economy or of democratizing social life. Therefore, the article compares CEE countries with regard to selected manifesta- 
tions of inconsistencies in institutional systems that are caused by the culturally rooted attitudes and values of their societies. Thus, indirectly, the author points to the important role of informal institutions in shaping coherent institutional system of CEE economies.

Keywords: informal institutions, transformation, postcomunists countries, corruption, trust.

\section{Wstęp}

Kraje Europy Środkowej i Wschodniej wchodziły w świat państw demokratycznych, zmieniając system polityczny i gospodarczy w sposób specyficzny, nieznany w przeszłości. W wyniku transformacji w krajach tych został wprowadzony, dominujący w świecie gospodarek rozwiniętych, system demokratyczny oraz neoliberalny model gospodarki rynkowej. Po ponad 25 latach transformacji widoczne są realne skutki modernizacji gospodarczej, politycznej i społecznej w omawianych państwach (zob. np. [Baszyński i in. 2013, s. 223-241]. Jednakże rodzi się pytanie: czy okres transformacji ustrojowej w państwach Europy Środkowej i Wschodniej można uznać za zakończony? W odniesieniu do krajów, które weszły w struktury UE, dominuje pogląd, iż proces ten uległ zwieńczeniu. Jednak nie można nie dostrzegać również wielu problemów, z jakimi boryka się na co dzień ta część naszego kontynentu. Pomimo współdziałania w rozwoju politycznym Unii Europejskiej oraz wielu prób tworzenia spójnej europejskiej społeczności, wciąż istnieją rażące dysproporcje między rozwiniętą Europą Zachodnią a europejskimi państwami postsocjalistycznymi. Przyczyn niedostatecznych efektów transformacji gospodarczej autorka upatruje w niespójnych systemach instytucjonalnych tych krajów.

Celem artykułu jest ukazanie istotnej roli podłoża kulturowego w procesie transformacji gospodarczej. Niespójne instytucje w krajach postkomunistycznych umożliwiają społeczeństwu utrwalanie postaw związanych z łamaniem podstawowych zasad funkcjonowania gospodarki rynkowej czy demokratyzacji życia społecznego. Mowa tu m.in. o utrzymującym się wysokim poziomie korupcji czy niskim poziomie zaufania w tych państwach. W części pierwszej artykułu autorka podejmie próbę zdefiniowania terminu spójności instytucjonalnej. Szeroko wykorzystana zostanie metoda krytycznej analizy literatury i wnioskowania logicznego. W części drugiej zawarta zostanie krótka charakterystyka uwarunkowań transformacji w analizowanych krajach. Jednocześnie autorka pragnie podkreślić, że wybrany zbiór badanych państw, choć posiada fundamentalną część wspólną - historyczną przynależność do bloku komunistycznego, różni wiele innych zmiennych (politycznych, kulturowych, gospodarczych). W trzeciej części dokonana zostanie analiza porównawcza omawianych państw pod kątem wybranych kulturowych przejawów niespójności instytucjonalnej. Analizą zostaną objęte postsocjalistyczne kraje europejskie, które obecnie są już pełnoprawnymi członkami Unii Europejskiej. 


\section{Konceptualizacja terminu spójność systemów instytucjonalnych}

Pojęcie instytucji zostało zapożyczone przez ekonomistów z dorobku innych nauk społecznych, głównie z prawa i socjologii. Sam termin „instytucja” pochodzi od łacińskiego institutiones, co oznaczało opracowanie zawierające podstawowe informacje z dziedziny prawa, mające charakter informacyjno-dydaktyczny. Według prawników, instytucja to zespół ściśle powiązanych ze sobą norm prawnych, w sposób funkcjonalny regulujących trwanie, powstanie lub ustanie jakiegoś stosunku prawnego (np. instytucja małżeństwa, instytucja własności, instytucja kontraktów rynkowych). Z kolei w socjologii instytucje są definiowane jako „stosunkowo stabilne zestawy wartości, norm, statusów [...], które związane są z pewnym specyficznym obszarem ludzkiej aktywności" [Goodman 1997, s. 55], bądź inaczej jest to „zbiór reguł związany z określonym kontekstem społecznym, realizujący podobne, istotne społecznie funkcje" [Sztompka 2002, s. 285].

W literaturze ekonomicznej zauważalny jest brak jednoznacznego sprecyzowania pojęcia ,instytucja”. Instytucje traktuje się jako: obowiązujące reguły gry społecznej, sposoby prowadzenia gier czy sposoby narzucania reguł $\mathrm{i}$ ich egzekwowania [North 2009], sposoby myślenia i postępowania ludzi, ujawniane w zachowaniach i zwyczajach grup i jednostek [Veblen 2008], systemy społecznych interakcji [Hodgson 2004], obowiązujące systemy przekonań i oczekiwań [Schooter 2008], wzorce zachowań [Aoki 2001] itd. Niektórzy autorzy rozszerzają tę listę o podmioty-organizacje [Hodgson 2006; Williamson 1998]. Okazuje się zatem, że nie jest łatwo określić, czym są instytucje. Tym trudniejsze staje się również określenie, jakimi wskaźnikami można je mierzyć i jak kontrolować ich wpływ na jednostki oraz ich aktywność.

Próby definiowania instytucji niejednokrotnie wiążą się z określeniem funkcji, jakie one pełnią. $\mathrm{W}$ tym zakresie w literaturze przedmiotu można zauważyć pewną zgodność autorów, którzy wśród funkcji instytucji wymieniają (za: [Staniek 2017, s. 83]:

- standaryzację zachowań w warunkach różnorodności jednostek i podmiotów gospodarczych, wpływ na preferencje;

- sprzyjanie zawieraniu kontraktów służących efektywnej kooperacji i koordynacji działań, zapewnienie bezpieczeństwa obrotu gospodarczego, zaufanie do rynków i państwa;

- obniżanie kosztów transakcyjnych (ale nie ich minimalizacja) w warunkach niepewności behawioralnej i rozgrywania gier o charakterze zarówno kooperacyjnym, jak i niekooperacyjnym;

- regulację funkcjonowania i rozwoju podmiotów gospodarczych, ułatwienia realizacji interesów podmiotów z uwzględnieniem różnych stron interesu publicznego;

- ograniczanie zakresu zjawisk typu market failures (zawodności rynku), jak i government failures (zawodności państwa); 
- sprzyjanie racjonalizacji skłonności do ryzyka, ograniczanie zakresu niepewności gospodarowania;

- wydłużanie horyzontu czasowego podejmowanych decyzji, umiejętne godzenie interesów „dziś” i interesów ,jutra”, kreowanie warunków sprzyjających wzrostowi gospodarczemu.

Niezależnie od różnic terminologiczno-definicyjnych w literaturze przedmiotu dzieli się instytucje na trzy typy: instytucje formalne (np. prawo, prawa własności, kontrakty, regulacje), instytucje nieformalne (normy społeczne, wzorce kulturowe, zwyczaje, zaufanie, sieci kontaktów i inne), instytucje - organizacje (przedsiębiorstwa, rynki, sieci, państwo).

Wszystkie typy instytucji - organizacji wraz z instytucjami formalnymi i instytucjami nieformalnymi składają się na system instytucjonalny [Staniek 2017, s. 50]. W każdej gospodarce istnieje zespół wzajemnie powiązanych instytucji, które kształtują zachowania ekonomiczne i społeczne. By gospodarka mogła osiągać wysokie tempo rozwoju, warunkiem koniecznym jest wykreowanie odpowiedniego środowiska instytucjonalnego [Casson, Giusta, Kambhampati 2010, s. 138]. Ten tzw. odpowiedni system instytucjonalny wymaga spójnego układu instytucji zwiększających stopień adaptacji systemu ekonomicznego jako całości.

Według słownika języka polskiego spójność określana jest jako „Zwartość, ścisła łączność". Zatem dla spójności systemów instytucjonalnych duże znaczenie ma komplementarność instytucji. W stabilnym systemie powoduje ona wzajemne wzmacnianie się poszczególnych instytucji oraz nasila ich inercyjność [Lissowska 2008, s. 97].

Komplementarne instytucje wiążą się z istnieniem zbieżnych celów między regułami formalnymi i nieformalnymi. Podstawowe normy prawne nie mogą istnieć bez oparcia w normach etycznych i moralnych. S. Pejovich sformułował ,tezę o interakcji”, w myśl której wzajemne oddziaływanie formalnych i nieformalnych instytucji jest zasadniczym czynnikiem oddziałującym na stabilność ekonomiczną i stopę wzrostu gospodarczego. Stwierdził bowiem: „Jeśli zmiany formalnych reguł są w harmonii z powszechnie przyjętymi regułami nieformalnymi, to interakcje między ich bodźcami będą redukować w społeczeństwie koszty transakcyjne i porządkować zasoby tak, aby sprzyjały tworzeniu bogactwa. Gdy nowe reguły formalne znajdują się w konflikcie $\mathrm{z}$ regułami nieformalnymi, to interakcje między ich bodźcami będą zwiększać koszty transakcyjne i ograniczą możliwość tworzenia bogactwa w społeczności” [Pejovich 1999, s. 171].

Można zatem wyróżnić różne poziomy relacji między instytucjami formalnymi a nieformalnymi: (1) formalne instytucje thumią, lecz nie zmieniają nieformalnych instytucji; (2) formalne zasady bezpośrednio kolidują z ograniczeniami nieformalnymi; (3) formalne reguły są ignorowane lub neutralne w stosunku do nieformalnych reguł; (4) formalne i nieformalne reguły współpracują ze sobą [Chavance 2010, s. 60]. W tym zakresie, w którym normy moralne oraz prawne są zgodne, presja wewnętrzna i zewnętrzna na postępowanie jednostek jest większa i bardziej jedno- 
znaczna. Od stopnia zgodności norm zinternalizowanych i prawnych zależy stopień przestrzegania prawa [Bossak 2008, s. 25]. Nieformalne instytucje mogą spowolnić pozytywne skutki nowych zasad formalnych, ale mogą również ograniczyć negatywne skutki nowych, niejednokrotnie błędnych instytucji formalnych [Chavance 2010, s. 61]. Od jakości i spójności instytucji zależy to, jak działa rynek, wykorzystywane są zasoby i jak dzielone są efekty gospodarowania [Wilkin 2014, s. 52].

Wielokrotnie w literaturze ekonomicznej pojawia się pogląd, iż sukces krajów kapitalistycznych w dużej mierze jest wynikiem współdziałania i spójności kulturowo zakorzenionych instytucji nieformalnych oraz instytucji formalnych. Williamson i Mathers [Williamson, Mathers 2011] na przykładzie badań panelowych 74 państw stwierdzają, że: 1) kultura zwiększa skuteczność instytucji gospodarczych; 2) wolność gospodarcza (charakteryzująca tzw. dobre instytucje) przyczynia się do dobrobytu gospodarczego oraz 3) efektywność jest silnie uzależniona od wartości kulturowych. Badania te potwierdzają, że kultura uwzględniona w zbiorze nieformalnych zasad determinuje sukces lub niepowodzenie formalnych instytucji gospodarczych, działając jako filtr efektywności wolności gospodarczej i kapitalizmu [Petrou, Daskalopoulou 2014, s. 1500].

Harmonia między instytucjami formalnymi i nieformalnymi warunkuje sukces gospodarczy w długim okresie, jednak rozbieżność może przeważać w różnym stopniu. Dla różnicowania systemów instytucjonalnych w gospodarce rynkowej istotne są takie czynniki, jak: poziom rozwoju, tradycje, kultura prawno-organizacyjna czy utrwalone normy zwyczajowe. Czynniki te powodują istnienie względnie trwałych odmienności systemowych. Podobne postawy jednostek i podmiotów wynikają ze wspólnej historii. Doświadczenia historyczne wskazują na ukształtowanie się różnych kultur czy systemów wartości społeczeństw gospodarki rynkowej towarzyszących osiąganiu bogactwa [Staniek 2017, s. 52].

\section{Uwarunkowania procesu transformacji w krajach Europy Środkowej i Wschodniej - podobieństwa i różnice}

Kraje Europy Środkowej i Wschodniej przebyły długą drogę reform mających na celu przede wszystkim demokratyzację struktur władzy państwowej, urynkowienie oraz prywatyzację gospodarki z wykorzystaniem doświadczeń państw zachodnich. Transformacja gospodarek socjalistycznych państw Europy Środkowej i Wschodniej rozpoczęła się w tym samym czasie historycznym, ale jej przebieg, kształt, dynamika i stopień zaawansowania, a co za tym idzie i rezultaty, są zróżnicowane w poszczególnych krajach. Wśród tych wyjątkowych dla każdego państwa czynników należy wymienić charakter sprawowania władzy przez aparat partii komunistycznych (reformatorska vs konserwatywna), stopień rozwoju gospodarczego, stopień zorganizowania opozycji demokratycznej, istnienie lub brak tradycji demokratycznej [Lechowicz 2015, s. 136]. 
Wspólną cechą omawianych krajów jest ich geopolityczne położenie w sąsiedztwie potężnych partnerów - Europy Zachodniej i Rosji. Tranzytowy charakter tego regionu przełożył się na dramatyczną jego historię, pełną krwawych konfliktów, najazdów, rozbiorów i wojen. Rozpoczęły się tu największe w historii konflikty zbrojne, tj. I i II wojna światowa. Szczególne położenie nałożyło na ten obszar istotne role w dziejach całej Europy [Kozłowska 2011, s. 102]. Był to więc region destabilizacji, która z natury nie sprzyjała rozwojowi społeczno-gospodarczemu. Po II wojnie światowej, w wyniku decyzji odgórnych, w krajach tych zapanował system gospodarki socjalistycznej, centralnie kierowanej. Z omawianej grupy krajów jedynie Słowenia miała specyficzny ustrój, gdyż wchodziła w skład byłej Jugosławii, która po 1948 r. zerwała bliskie relacje z ZSRR i nie była tym samym od niego uzależniona.

Szybkość i zakres reform gospodarczych przeprowadzanych w państwach postsocjalistycznych $\mathrm{w}$ pierwszych latach transformacji były zależne od wielu czynników, w tym od sprawującego w nich władzę układu sił politycznych. Rządy reprezentujące nowe siły polityczne realizowały bardziej radykalne programy prowadzące do liberalizacji gospodarki. Taką politykę prowadzono m.in. w Polsce, w byłej Czechosłowacji i na Węgrzech. Inaczej natomiast kształtowała się sytuacja w państwach, w których nie nastąpiły zmiany w politycznym przywództwie [Jóźwik 2016, s. 54-55]. Litwa, która w latach 1992-1993 miała wprawdzie radykalne podejście do prywatyzacji, jednocześnie przejawiała wahania w podejściu do stabilizacji makroekonomicznej. Natomiast w państwach byłej Jugosławii dynamika prywatyzacji utrzymywała się na przeciętnym poziomie. Pewne jej przyspieszenie odnotowano dopiero pod koniec lat 90 . XX wieku, m.in. w wyniku zakończenia wojen oraz perspektywy integracji z Unią Europejską. Słowenia przystąpiła do Unii Europejskiej w roku 2004, a Chorwacja w 2013 [Jóźwik 2016, s. 54-55]. Zupełnie odrębny przypadek dotyczył z kolei Rumunii i Bułgarii, gdzie system władzy autorytarnej miał najbardziej stabilne fundamenty sprawowania rządów, kultura buntów społecznych była najsłabsza, a struktury opozycyjne powstawały w nader ograniczony sposób. Transformacja polegała tam na stopniowej, kontrolowanej przez rząd komunistyczny liberalizacji systemu poprzez ograniczone dołączanie do tego procesu sił opozycyjnych, którym w ostateczności przypadła w nim w zasadzie drugoplanowa rola [Lechowicz 2015, s. 140].

Do specyfiki wschodnioeuropejskich przekształceń ustrojowych należy m.in. zróżnicowana liczba równoległych procesów transformacyjnych, z którymi musiały sobie poradzić społeczeństwa, gospodarki i państwa. W Polsce, w Czechach, na Węgrzech i w kilku innych środkowoeuropejskich krajach transformacja ustrojowa oznaczała zmianę systemu gospodarczego i politycznego. W państwach, które powstały w wyniku rozpadu ZSRR, do tych dwóch głównych procesów przekształceń doszedł jeszcze jeden - tworzenie, kształtowanie lub rozbudowa instytucji niepodległego państwa [Konieczna-Sałamatin 2016, s. 300].

Postępująca transformacja miała szybki, a w niektórych przypadkach szokowy charakter. Okazało się to poważnym problemem, pełnych i szerokich zmian syste- 
mowych bowiem nie sposób przeprowadzić w krótkim czasie, nie czekając na trwałą akceptację nowych instytucji państwa w życiu publicznym zarówno przez podmioty gospodarujące, jak i przede wszystkim przez społeczeństwo [Kleer, Kleiber 2015, s. 88]. Demokracja w większości społeczeństw nie była powszechnie i głęboko zakorzeniona. W zasadzie wszelkie pozostałości doświadczeń demokratycznych zniszczył eksperyment socjalistyczny. Owe prawno-instytucjonalne normy nałożone zostały na rzeczywistość społeczną wykreowaną w głównej mierze przez kilkadziesiąt lat realnego socjalizmu, czyli rzeczywistość układów personalnych, działań pozornych, osobowości łatwej we współżyciu czy próżni socjologicznej i amoralnego familizmu [Rosół 2011, s. 55]. Dużym problemem stało się przyjęcie indywidualistycznych reguł działania przez poszczególnych aktorów. Przezwyciężenie nabytych i często przez pokolenia przekazywanych przyzwyczajeń jest zwykle zabiegiem trudnym. Ludzie często boją się niesprawdzonych nowości, a upowszechnienie korzyści z większych lub mniejszych nowinek wymaga pozytywnego doświadczenia zbiorowego. Zmiany w mentalności i zachowaniach ludzi zajmują zazwyczaj więcej czasu niż jedno pokolenie.

Interakcje między wzorcami instytucjonalnymi implementowanego anglosaskiego kapitalizmu i dziedziczonymi po gospodarce centralnie planowanej instytucjami w krajach przechodzących proces transformacji mogą prowadzić do negatywnych skutków w postaci degradacji kapitału społecznego i formowania się ujemnego kapitału społecznego. Przejawem tego są rosnące wskaźniki korupcji, przestępczości (w tym oszustw podatkowych), ubóstwa i wykluczania społecznego, skutkujące syndromem wyuczonej bezradności, spadkiem reputacji polityki i zaburzeniami w stabilności wzrostu gospodarczego, wysokimi wskaźnikami bezrobocia i przejściowym obniżeniem się PKB per capita [Woźniak 2009].

\section{Znaczenie kultury w tworzeniu spójnych systemów instytucjonalnych}

Ważnym składnikiem przesądzającym o systemie instytucjonalnym jest system kulturowy. Ma on olbrzymi wpływ na wewnętrzne interakcje zarówno w relacjach między władzą publiczną a społeczeństwem, jak i w obrębie samego społeczeństwa oraz w relacjach zewnętrznych. System kulturowy jest w dużym stopniu skorelowany $\mathrm{z}$ innym ważnym składnikiem, jakim są warunki przesądzające o ludzkiej kreatywności i skłonności do zmian w podejmowaniu ryzyka gospodarczego [Kleer, Kleiber 2015, s. 33]. Jeśli kultura transformującego się społeczeństwa dobrze koegzystuje z gospodarką wolnorynkową, istnieje szansa na sukces w postaci włączenia kapitalistycznych wzorców, postaw i standardów działania w całość wzorców, postaw i standardów akceptowanych w danym społeczeństwie i przekształcenie go w jeden spójny aksjologicznie i prakseologicznie organizm. Jeśli jednak środowisko kulturowe jest nieprzyjazne, jak uważa M. Bucholc, model gospodarki wolnorynkowej mógłby się przekształcić w inny, bardziej zgodny z charakterem danej kultury lub 
mogłoby nastąpić obudowywanie go treściami kulturowymi sprzecznymi z tymi, na bazie których powstał sam model. Receptą na niedopuszczenie do zaistnienia którejś $\mathrm{z}$ tych sytuacji jest próba przenoszenia modelu gospodarowania (wolnorynkowej gospodarki) wraz z jego tłem kulturowym [Bucholc 2007, s. 61]. W społeczeństwach przechodzących transformację systemową powinna wobec tego zajść również transformacja kulturowa.

Ze względu na to, że model gospodarki wolnorynkowej, będącej elementem wdrożenia w krajach Europy Środkowej i Wschodniej, kształtował się wraz z systemem wartości i norm tych społeczeństw, stanowił integralną część środowiska kulturowego tych krajów. Tym samym można przypuszczać, że systemy instytucjonalne krajów Europy Zachodniej są w miarę spójne. Tymczasem stosunkowo inny system wartości uznawany przez społeczeństwa państw wschodnioeuropejskich wymusza jego zmianę w kierunku postaw i wartości obserwowanych w krajach Europy Zachodniej.

U progu transformacji system norm i wartości społeczeństw wschodnioeuropejskich nie mógł w takim stanie być podstawą gospodarki rynkowej. Dominujące wzorce zachowań to bierność i zachowawczość, roszczeniowość w stosunku do państwa. Negatywnie odnoszono się do odmienności, oryginalności. Z drugiej strony, wśród wartości występowała chęć pomocy innym i ochrona słabszych [Gruszewska 2012].

Obecnie, po długoletnim okresie transformacji krajów Europy Środkowej i Wschodniej, można zauważyć, iż występujące zmiany w systemach wartości omawianych społeczeństw następują stosunkowo wolno. Postkomunistyczne kraje Europy Środkowej i Wschodniej, choć w większości lokują się w wymiarze wartości świeckich i racjonalistycznych (charakterystycznych dla społeczeństw wysoko rozwiniętych), pozostają wciąż przy wartościach materialistycznych, zaabsorbowane potrzebami przetrwania i bezpieczeństwa. Państwa postkomunistyczne Europy Środkowej (Polska, Czechy, Słowacja, Słowenia i Węgry) lokują się na pograniczu Europy Zachodniej i Wschodniej nie tylko geograficznie, lecz także pod względem wskaźników akceptowanych wartości tradycjonalnych (najsilniejszych w Polsce) i świecko-racjonalnych (w których przodują Czesi), wartości materialistycznych (przeważających na Węgrzech) i postmaterialistycznych (częstszych w Czechach i Słowenii) [Gruszewska 2012; Jasińska-Kania (red.) 2012; Owczarczuk 2013].

Jak twierdzi A. Rosół: ,[...] nasz aktualny względny sukces zawisł na włosku indywidualizmu wprowadzonego w pierwszych latach transformacji. Zmiany instytucjonalne nie zostały bowiem dokończone, przez co niejako zahamowaniu uległ proces przekształceń mentalnych" [Rosół 2011, s. 54]. Zbyt wolne dostosowywanie się systemów wartości w społeczeństwach wschodnioeuropejskich do wprowadzonego modelu wolnorynkowego powoduje rozwój bądź zahamowanie pewnych zachowań.

Typowe przejawy wynikające z niespójności systemów instytucjonalnych postsocjalistycznych państw Europy Środkowej i Wschodniej są związane m.in. z łamaniem podstawowych zasad funkcjonowania gospodarki rynkowej. Należą do nich 
m.in. oszustwa podatkowe czy wysoki poziom korupcji. Uczciwość zaś, przejawiana na różne sposoby, należy do podstawowych norm etycznych.

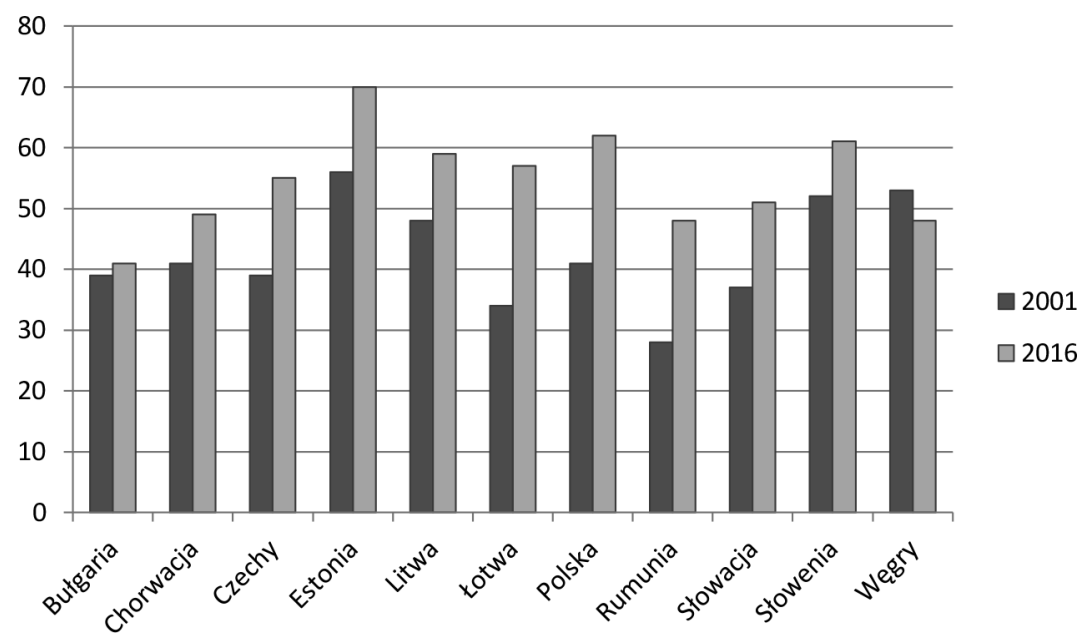

Im niższe wartości przyjmuje indeks, tym większy poziom postrzeganej korupcji.

Rys. 1. Wskaźniki postrzeganej korupcji w krajach EŚiW w latach 2001 i 2016

Źródło: opracowanie na podstawie [Corruption Perception Index].

Zmiany wskaźnika postrzeganej korupcji w większości państw regionu EŚiW przebiegają w pożądanym kierunku (rys. 1). Jedynie na Węgrzech wartość wskaźnika się obniżyła, co oznacza, że kraj ten w 2016 r. postrzegany był jako bardziej skorumpowany niż w 2001 roku. W większości analizowanych państw dostrzega się nadal wysoki, w porównaniu z krajami Europy Zachodniej, poziom postrzeganej korupcji. Wskaźnik w większości państw nie przekroczył 50, podczas gdy w wielu wysoko rozwiniętych krajach europejskich przekracza on poziom 70 (Dania - 90, Finlandia-89, Szwecja-88, Szwajcaria-86, Norwegia - 85, Wielka Brytania-81, Niemcy - 81). Najniższy poziom postrzeganej korupcji jest w Estonii, najwyższy zaś w Bułgarii, Chorwacji i Rumunii. Są to jednocześnie najbiedniejsze i najmłodsze kraje UE. Istniejące kłopoty związane z jakością prawa i administracji publicznej oraz liczne incydenty na tle etnicznym, w które w Rumunii zaangażowana jest mniejszość węgierska i romska, a w Bułgarii turecka i romska, stają się czynnikiem dodatkowo obniżającym zaufanie do instytucji państwa.

Uczciwość w życiu publicznym, jak i gospodarczym bywa zasobem, który wynagradza w tym sensie, że społeczeństwo jest bardziej przyjazne wobec jednostki, transakcje między ludźmi nie muszą być obwarowane piętrowymi zabezpieczeniami przed oszustwem (zwiększającymi koszty transakcyjne), a relacje międzyludzkie oparte są na zaufaniu. Gdy mamy do czynienia z deficytem uczciwości, państwo nie 
ufa obywatelom, obywatele odnoszą się nieufnie do instytucji własnego państwa, a także do siebie nawzajem. Zależność jest tu następująca: wysoka korupcja na poziomie władzy, administracji i aparatu kontrolnego równa się niskiemu zaufaniu pośród obywateli. Istnieje więc wyraźna korelacja między wysoką zdiagnozowaną korupcją w ramach instytucji porządku publicznego (sądy, policja) a niskim poziomem uogólnionego zaufania [Szlendak 2015, s. 355]. Z drugiej strony zaś w sytuacji, gdy brakuje zaufania lub jest ono na niskim poziomie, pojawiają się jego funkcjonalne substytuty w postaci zachowań oportunistycznych (klientelizm, nepotyzm, korupcja) [Kietliński 2009, s. 102].

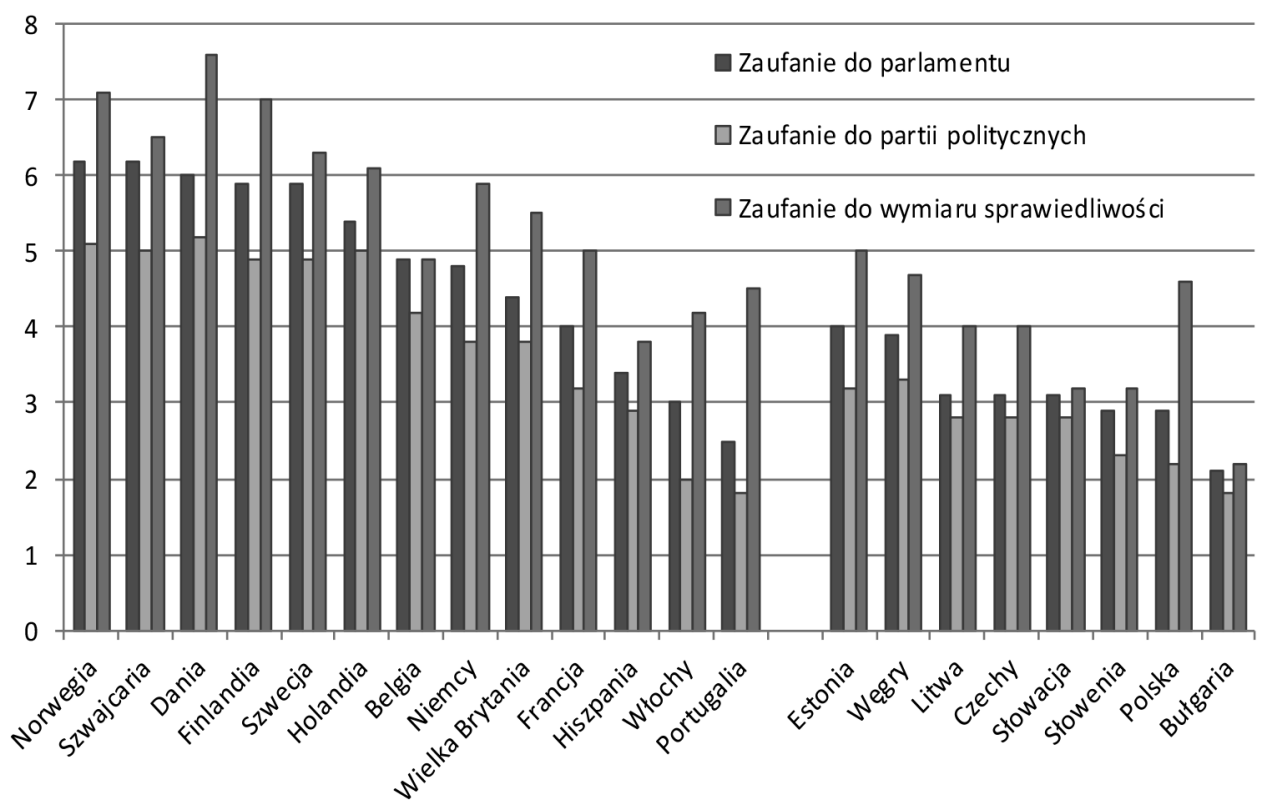

Badani odpowiadali na następujące pytanie: „Proszę wskazać na skali od 0 do 10, na ile osobiście masz zaufanie do parlamentu, do partii politycznych, do wymiaru sprawiedliwości”. 0 - oznacza brak zaufania, 10 - pełne zaufanie.

Rys. 2. Średnie zaufanie do parlamentu, partii politycznych i wymiaru sprawiedliwości w Europie w 2012 r.

Źródło: [Europejski Sondaż Społeczny].

Niskim zaufaniem darzą polityków mieszkańcy niemal wszystkich państw postkomunistycznych (zob. rys. 2). Spośród analizowanych państw istotnie wyróżnia się Estonia, w której średni poziom zaufania do wymienionych instytucji publicznych jest nawet wyższy niż w niektórych państwach z Europy Zachodniej. Najniższym poziomem zaufania do parlamentu, partii i sądów odznacza się Bułgaria. 
Wśród wyszczególnionych instytucji publicznych najmniejszym zaufaniem obdarzane są partie polityczne. W krajach postkomunistycznych Europy Środkowej i Wschodniej wartość wskazań na tę instytucję oscylowała wokół 3 punktów. Niskim zaufaniem respondenci darzą również parlament. Najwyższym zaufaniem wśród mieszkańców Europy (oraz państw EŚiW) cieszy się wymiar sprawiedliwości. O ile brak zaufania do parlamentu i partii politycznych jest $w$ analizowanych krajach spuścizną kilkudziesięciu lat funkcjonowania społeczeństwa we wrogim mu środowisku instytucjonalnym i biurokratycznym, o tyle większe zaufanie do wymiaru sprawiedliwości może być przejawem zwiększenia przejrzystości prawa i jego egzekwowalności. Niemniej jednak teza ta wydaje się nazbyt pochopna, ponieważ zaufanie, jakim darzony jest wymiar sprawiedliwości w krajach EŚiW, oceniane jest również stosunkowo nisko (na mniej niż 5 punktów).

Podobnie jak parlament mieszkańcy krajów postsocjalistycznych traktują policję i system prawny [Szlendak 2015, s. 341]. Na niskim poziomie w krajach Europy Środkowej i Wschodniej kształtuje się również zaufanie ogólne ${ }^{1}$. Należy jednak wziąć pod uwagę fakt, że kultura zaufania, oprócz tego, że jest tworem historycznym, to jest też wynikiem działań intencjonalnych w takim sensie, że wymaga celowego, przemyślanego tworzenia solidnej obudowy instytucjonalnej. Jak stwierdza T. Szlendak: ,[...] kultura zaufania to produkt historii, to efekt kumulacji indywidualnych mikrohistorii w ramach działań zbiorowych w mozolnie budującym się za sprawą tych mikrohistorii środowisku instytucjonalnym. Tworzy się setki lat, jak w wypadku Skandynawii. Instytucje stają się niezbędne jako obudowy dla zaufania" [Szlendak 2015, s. 353].

\section{Zakończenie}

Rozważania przeprowadzone w artykule miały na celu ukazanie istotnej roli środowiska kulturowego w formowaniu spójnego systemu instytucjonalnego. Mając na uwadze różnorodność determinantów warunkujących proces transformacji dokonany w postsocjalistycznych gospodarkach Europy Środkowej i Wschodniej, próbowano wskazać na istotną rolę zmiennych kulturowych, które niejednokrotnie były i są omijane podczas wprowadzania nowych rozwiązań instytucjonalnych.

Po ponad 25 latach od rozpoczęcia transformacji gospodarczej w analizowanych krajach można zauważyć pewne symptomy niespójnych instytucji. Wolnorynkowe zasady działania i tradycjonalistyczny system wartości dominujący w społeczeństwach tych krajów prowadzą do utrwalania się lub wyłaniania wielu niepożądanych

\footnotetext{
${ }^{1}$ Na pytanie: „Czy ogólnie biorąc, uważasz, że większości ludzi można ufać, czy też w kontaktach z ludźmi ostrożności nigdy za wiele?" jedynie w Estonii i Czechach nieco ponad 30\% respondentów odpowiedziało pozytywnie, podczas gdy w pozostałych państwach odsetek odpowiedzi na takie pytanie oscylował wokół 20\% [Europejski Sondaż Społeczny].
} 
postaw, które z kolei oddziałują destymulująco na gospodarki. Kraje te charakteryzuje wciąż wysoki poziom korupcji oraz niski poziom zaufania.

Dokonana refleksja nad przemianami zachodzącymi w Europie Środkowej i Wschodniej może służyć wielu celom. Analiza teorii i praktyki przekształceń systemowych i ich ocena mają znaczenie nie tyle retrospektywne, ile prospektywne. Umożliwiają głębsze poznanie zarówno szans, jak i zagrożeń rozwojowych krajów transformujących się oraz tych, które są w stadium posttransformacyjnym, a na tej podstawie - formułowanie wniosków co do ich strategii gospodarczej obejmującej zarówno politykę gospodarczą, jak i system funkcjonowania gospodarki. Bezsprzecznie większość analizowanych państw potrzebuje kompleksowej, długofalowej strategii rozwoju wspartej jednak w dużej mierze normami i wartościami charakteryzującymi społeczeństwa danych krajów. Dlatego też można stwierdzić, że wciąż jeszcze kształtujący się model gospodarki rynkowej w tych państwach powinien przybierać różne oblicza, silniej umocowane w kulturze danych społeczeństw.

\section{Literatura}

Aoki M., 2001, Toward a Comparative Institutional Analysis, The MIT Press Cambridge, London.

Baszyński A., Jarmołowicz W., Piątek D., Szarzec K., 2013, Przebieg i rezultaty transformacji gospodarczej w wybranych krajach europejskich, [w:] Bludnik I., Ratajczak M., Wallusch J. (red.), Ekonomia. Teoria, historia, praktyka, Wydawnictwo Uniwersytetu Ekonomicznego w Poznaniu, Poznań.

Bossak J.W., 2008, Instytucje, rynki i konkurencja we współczesnym świecie, Oficyna Wydawnicza SGH, Warszawa.

Bucholc M., 2007, Ryzyko przeszczepu kultury gospodarczej, [w:] Kochanowicz J., Mandes S., Marody M. (red.), Kulturowe aspekty transformacji ekonomicznej, ISP, Warszawa.

Casson M.C., Giusta M.D., Kambhampati U.S., 2010, Formal and informal institutions and development, World Development, vol. 38, no. 2, s. 137-141.

Chavance B., 2010, Formal and Informal Institutional Change: the Experience of Postsocialist Transformation, The European Journal of Comparative Economics, vol. 5, no. 1, s. 57-71.

Corruption Perception Index, https://www.transparency.org/news/feature/corruption_perceptions_index_2016,(11.03.2017).

Europejski Sondaż Społeczny, http://www.europeansocialsurvey.org/, (11.03.2017).

Goodman N., 1997, Wstęp do socjologii, Wydawnictwo Zysk i S-ka, Poznań.

Gruszewska E., 2012, Transformacja instytucji nieformalnych w Polsce, Gospodarka Narodowa, nr 3, s. 61-83.

Hodgson G.M., 2004, The Evolution of Institutional Economics. Agency, Structure and Darwinism in American Institutionalism, Routledge, London - New York.

Hodgson G.M., 2006, What are institutions?, Journal of Economic Issues, vol. XL, no. 1, s. 1-25.

Jasińska-Kania A. (red.), 2012, Zmiany wartości Polaków a procesy transformacji, europeizacji i globalizacji, [w:] Jasińska-Kania A. (red.), Wartości i zmiany. Przemiany postaw Polaków w jednoczacej się Europie, Wydawnictwo Naukowe Scholar, Warszawa.

Jóźwik B., 2016, Transformacja i rozwój gospodarczy w państwach Europy Środkowo-Wschodniej, [w:] Transformacja, integracja i kryzysy w Europie Środkowo-Wschodniej, Rocznik Instytutu Europy Środkowo-Wschodniej, z. 5. 
Kietliński K., 2009, Moralność gospodarki opartej na wiedzy, Wydawnictwo Uniwersytetu Kardynała Stefana Wyszyńskiego, Warszawa.

Kleer J., Kleiber M., 2015, Zagrożenia globalne barierami rozwoju, Komitet Prognoz „Polska 2000 Plus" przy Prezydium Polskiej Akademii Nauk, Warszawa.

Konieczna-Sałamatin J., 2016, Wschodnioeuropejskie transformacje. Wzrost PKB w czasie jako miara sukcesu transformacji, Studia Prawno-Ekonomiczne, t. XCIX, s. 293-308.

Kozłowska M., 2011, Europejskie kraje postsocjalistyczne - kraje zakończonej transformacji systemowej, [w:] Swadźba S. (red.), Systemy gospodarcze. Analiza porównawcza, Katowice.

Lechowicz P., 2015, Tranzycja demokratyczna w Europie Środkowej $i$ Wschodniej. Proces przeksztatceń społeczno-politycznych w świetle założeń teorii rewolucji-szkoły socjologii historycznej, [w:] Barański M., Rudakiewicz N., Guza M. (red.), Doświadczenia transformacji systemowej w państwach Europy Środkowej i Wschodniej, Wydawnictwo Uniwersytetu Śląskiego, Katowice.

Lissowska M., 2008, Instytucje gospodarki rynkowej w Polsce, Wydawnictwo C.H. Beck, Warszawa.

North D.C., 2009, Institutions, Institutional Change and Economic Performance, The Cambridge University Press.

Owczarczuk M., 2013, Kultura ekonomiczna regionu. Polska na tle Unii Europejskiej, [w:] Dynamika, cele i polityka zintegrowanego rozwoju regionów. Perspektywa europejska, Bogucki Wydawnictwo Naukowe, Poznań.

Pejovich S., 1999, The Effects of the Interaction of Formal and Informal Institutions on Social Stability and Economic Development, Journal of Markets \& Morality, vol. 2, no. 2, s. 164-181.

Petrou A., Daskalopoulou I., 2014, Is Greece a rent seeking society? A research on the relationship between entrepreneurship, trust and institutions, Social Indicators Research, vol. 119, issue 3, s. $1495-1515$.

Poliński R., 2011, Reformy gospodarcze i transformacja systemów ekonomicznych w krajach Europy Środkowo-Wschodniej, ALMAMER Szkoła Wyższa, Warszawa.

Rosół A., 2011, Dwadzieścia lat transformacji. Między indywidualizmem a kolektywizmem [w:] Walczak-Duraj D. (red.), Aksjologiczny i pragmatyczny wymiar współczesnej polityki, Wydawnictwo Uniwersytetu Łódzkiego, Łódź.

Schotter A., 2008, The Economic Theory of Social Institutions, Cambridge University Press, Cambridge, s. 11.

Staniek Z., 2017, Ekonomia instytucjonalna. Dlaczego instytucje sa ważne, Difin, Warszawa 2017.

Szlendak T., 2015, Zaufanie, [w:] Boguni-Borowska M. (red.), Fundamenty dobrego społeczeństwa. Wartości, Wydawnictwo Znak, Kraków.

Sztompka P., 2002, Socjologia, Wydawnictwo Znak, Kraków.

Veblen T., 2008, Teoria klasy próżniaczej, Warszawskie Wydawnictwo Literackie Muza, Warszawa.

Wilkin J., 2014, Zagrożenia globalne wynikające ze zmian strukturalnych i instytucjonalnych [w:] Kleer J., Mączyńska E., Michałek J.J., Niżnik J. (red.), Kryzysy systemowe, Komitet Prognoz „Polska 2000 Plus" przy Prezydium Polskiej Akademii Nauk, Warszawa 2014.

Williamson C.R., Mathers R.L., 2011, Economic freedom, culture and growth, Public Choice, vol. 148, s. 313-335.

Williamson O., 1998, Ekonomiczne instytucje kapitalizmu: firmy, rynki, relacje kontraktowe, Wydawnictwo Naukowe PWN, Warszawa.

Woźniak G.M., 2009, Instytucjonalne uwarunkowania wzrostu gospodarczego i sprawiedliwych nierówności społecznych, Nierówności Społeczne a Wzrost Gospodarczy, z. 14, s. 39-54. 